\title{
Decreasing Level of Plumbum (Pb) Chromium (CR) In Sea Water With Soil Layer Media (Montmorillonite)
}

\author{
Erwin Azizi Jayadipraja ${ }^{1}$, Fitri Rachmilla Fadmi ${ }^{2}$, Suardin Suardin ${ }^{3}$, Ramadhan Tosepu ${ }^{4}$ \\ \{erwinazizijayadipraja@gmail.com ${ }^{1}$ \} \\ ${ }^{1,2}$ College of Mandala Waluya Health School, Kendari, Indonesia \\ ${ }^{3}$ South Konawe Health Departement, Asera, Indonesia \\ ${ }^{4}$ Faculty of Public Health, Halu Oleo University Kendari, Indonesia
}

\begin{abstract}
Various studies have found the presence of heavy metal contamination in Kendari bay. Heavy metals can have implications for the health of residents living around Kendari Bay. Therefore, it is necessary to do seawater treatment to reduce the heavy metal content. The objective of this study is to reduce the heavy metal content of Plumbum $(\mathrm{Pb})$ and Chromium (Cr) in seawater. The study employed quasi-experimental Nonequivalent Control Group Design. This study tested the decrease in the levels of heavy metals Plumbum $(\mathrm{Pb})$ and Chromium (Cr) using the Atomic Absorption Spectrophotometry (AAS) method after flowing in the Montmorillonite medium. The results showed the highest decrease in $\mathrm{Pb}$ and $\mathrm{Cr}$ levels with variation in elevation of $80 \mathrm{~cm}$ using Montmorillonite and 100 minutes, each of them is $41 \%$ and $50 \%$. The results of data analysis for $\mathrm{Pb}$ Level using the One Way ANOVA test obtained $p$-value values $(0.000)<\alpha(0.05), \mathrm{Cr}$ levels obtained $p$-value value $(0.000)<\alpha(0.05)$. The concentration of seawater tested has decreased the strength of heavy metals after flowing through the medium of Montmorillonite. It should be noted that the decrease in salinity so that water can be used in fulfilling the daily needs of the community.
\end{abstract}

Keywords: Sea Water,Plumbum, Kromium, Kendari, Indonesia.

\section{Introduction}

Water is one of the important commodities that sustains and maintains our lives on earth and can be easily obtained from our environment. There are about $97 \%$ of the water on earth is sea water, while fresh water in the entire world is only about $0.5 \%$. About $41 \%$ of the world's population lives in arid regions, while those who get access to water from rivers have been threatened by pollution of the environment [1]. According to the United Nations, about 1.2 billion people live in areas with very scarce water access, another 500 million people approach this situation and 1.6 billion people (a quarter of the world's population) face a lack of water. Some of the obvious negative effects of water scarcity can be seen from the figures provided by WHO, in which more than 3.4 million people die each year due to water cleanliness-related causes [2].

Human activities, such as industrial production, mining, agriculture and transportation, release large amounts of heavy metals to the surface and ground water, soil and finally to the biosphere. Pollution occurs almost in all over the world and all elements, both air pollution that endangers health [3] and water pollution that has implications for public health [4]. The high level of 
pollution that occurs, especially in sea water is the implication of the consequences of human activity on land, specifically due to contamination of heavy metals [5] in developing countries [6]. The most important source of heavy metals in the environment is anthropogenic activities such as mining, smelting procedures, steel and iron industry, chemical industry, traffic, agriculture and domestic activities. Heavy metal pollution in the aquatic environment is a growing problem throughout the world and has now reached an alarming level. There are various sources of heavy metals; some come from anthropogenic activities such as draining drains, Hospital waste disposal and recreational activities. In contrast, metals also occur in small amounts naturally and can enter into aquatic systems through rock washing, airborne dust, forest and plant fires. Since heavy metals cannot be degraded, they are continuously stored and put into water, causing heavy metal pollution in the body of water to the sea [7],[8],[9].

Therefore, it is necessary to do sea water treatments for people who have very limited access to water. One of them is the ion exchange method using a natural resin namely clay (Montmorillonite) [10]. Montmorillonite works in helping the ion exchange process. Ion exchange using clay is very efficient in reducing the concentration of heavy metals in sea water and it is also considered economical because clay is an easily available natural resin which is widely available in nature [11]. The character of local mineral adsorbent generally occurs because of the formation of a molecular structure framework from the incorporation of tetrahedral molecules to form regular gaps and channels causing a porous structure. Gaps and channels in the structure that occur allow a molecule that may pass through it to be trapped in it. These properties that make clay local minerals can be used as absorbent materials for hazardous metals in liquid waste, molecular filters and as ion exchangers [12].

One method used to improve the ability of Montmorillonite as an adsorbent and a catalyst is by pilarization or the formation of clay composites with metal oxides. Generally, Montmorillonite is disbursed with various organic compounds, complex compounds and metal oxides which are intercalated into inter-layer. This disbursement process can cause the clay pores to become larger and homogeneous, inter-layer is relatively stable than before it is disbursed. Through calcinations, a metal oxide pillar is obtained. It will support the inter-layer space of the Montmorillonite [13]. Thus, this study aims to examine the decrease in $\mathrm{Pb}$ and $\mathrm{Cr}$ concentrations in sea water using Montmorillonite.

\section{Method}

This study is a type of quasi experiment Non-equivalent Control Group Design study. This study tested the decrease in the levels of heavy metals Plumbum $(\mathrm{Pb})$ and Chromium $(\mathrm{Cr})$ using the Atomic Absorption Spectrophotometry (AAS) method after flowing in the Montmorillonite medium. This study used treatments of high variety of variation in elevation of pillared Montmorillonite soil per 100 minutes which consisted of 3 measurements of high altitude, i.e. 40 $\mathrm{cm} / 100$ minutes, $60 \mathrm{~cm} / 100$ minutes and $80 \mathrm{~cm} / 100$ minutes. The particle size of Montmorillonite is 200 mesh. The clay disbursement was carried out by adding $100 \mathrm{~mL}$ of aquadest and calcium phosphate solution $\mathrm{Ca} 3$ (PO4) $20.05 \mathrm{M}$. Sea water concentrated with $\mathrm{Pb}$ and $\mathrm{Cr}$ was taken in Kendari Bay ( $3^{\circ} 58^{\prime} 43.61^{\prime \prime} \mathrm{S}$ and $\left.122^{\circ} 32^{\prime} 53.26 " \mathrm{E}\right)$. Each treatment result was tested on $\mathrm{Pb}$ and $\mathrm{Cr}$ concentrations in the Health Laboratory of Southeast Sulawesi Province. 


\section{Result}

a. Concentration of Lead $(\mathrm{Pb})$

The test result of the sea water containing $\mathrm{Pb}$ on the pillared Montmorillonite with variations in elevation is presented in table 1.

Table 1. Concentration of $\mathrm{Pb}$ in three times of repetition.

\begin{tabular}{|c|c|c|c|c|c|}
\hline Treatment & $\begin{array}{l}\text { Control } \\
(\mathrm{mg} / \mathrm{L})\end{array}$ & $\begin{array}{c}40 \mathrm{~cm} / 100 \\
\text { minutes } \\
(\mathrm{mg} / \mathrm{L})\end{array}$ & $\begin{array}{c}60 \mathrm{~cm} / 100 \\
\text { minutes } \\
(\mathrm{mg} / \mathrm{L})\end{array}$ & $\begin{array}{c}80 \mathrm{~cm} / 100 \\
\text { minutes } \\
(\mathrm{mg} / \mathrm{L})\end{array}$ & $\begin{array}{c}\text { Quality } \\
\text { Standards }\end{array}$ \\
\hline 1 & \multirow{7}{*}{0.0076} & 0.0064 & 0.0052 & 0.0046 & \multirow{7}{*}{$\begin{array}{c}0.008 \mathrm{mg} / 1 \\
\text { (Kepmen } \\
\text { LH } \\
\text { 51/MenLH } \\
\text { /2004) }\end{array}$} \\
\hline 2 & & 0.0062 & 0.0057 & 0.0042 & \\
\hline 3 & & 0.0069 & 0.0058 & 0.0048 & \\
\hline Minimum & & 0.0062 & 0.0052 & 0.0042 & \\
\hline Maximum & & 0.0069 & 0.0058 & 0.0048 & \\
\hline Mean & & 0.0065 & 0.0055 & 0.0045 & \\
\hline SD & & 0.00036 & 0.00321 & 0.00305 & \\
\hline
\end{tabular}

Data Source: Analysis in 2018

Table 1 shows the concentration of $\mathrm{Pb}$ control is $0.0076 \mathrm{mg} / \mathrm{L}$, after flowing through the Montmorillonite, the concentration is decreased. Decrease in concentrations occurs in three variations in elevation with the lengths of Montmorillonite media of $40 \mathrm{~cm}, 60 \mathrm{~cm}$ and $80 \mathrm{~cm}$, the lowest decreases in sequence reach $0.0062 \mathrm{mg} / \mathrm{L}, 0.0052 \mathrm{mg} / \mathrm{L}$ and $0.0042 \mathrm{mg} / \mathrm{L}$.

Table 2. Percentage of decrease in Concentration of $\mathrm{Pb}$.

\begin{tabular}{|c|c|c|c|}
\hline Treatment & $\begin{array}{l}\text { Control } \\
(\mathrm{mg} / \mathrm{L})\end{array}$ & $\begin{array}{l}\text { Average Concentration } \\
\text { of } \mathrm{Pb}(\mathrm{mg} / \mathrm{L})\end{array}$ & $\begin{array}{c}\text { Percentage of } \mathrm{Pb} \\
(\%)\end{array}$ \\
\hline $40 \mathrm{~cm} / 100$ minutes & \multirow{3}{*}{0.0076} & 0.0065 & 14 \\
\hline $60 \mathrm{~cm} / 100$ minutes & & 0.0055 & 28 \\
\hline $80 \mathrm{~cm} / 100$ minutes & & 0.0045 & 41 \\
\hline
\end{tabular}

Data Source: Analysis in 2018

Table 2 shows that for concentration of $\mathrm{Pb}$ after flowing through Montmorillonite of $40 \mathrm{~cm}$, $60 \mathrm{~cm}$ and $80 \mathrm{~cm}$ has decreased. The highest decrease is in the third treatment group, i.e. 80 $\mathrm{cm} / 100$ minutes, with a decrease percentage of $41 \%$.

The analysis result of the One Way Anova test obtains value of Fcount (62.925) >Ftable (4.066) and $\mathrm{p}$-value $(0.000)<\alpha(0.05)$, then $\mathrm{H} 0$ is rejected. This means that there is a difference in the concentration of lead $(\mathrm{Pb})$ of sea water between pillared clay (Mortmorillonite) with variations in elevation of $40 \mathrm{~cm} / 100$ minutes, $60 \mathrm{~cm} / 100$ minutes and $80 \mathrm{~cm} / 100$ minutes.

Based on the analysis result using the LSD (Least Significant Difference) test on the treatment of variation in elevation, it can be seen the comparison between the control group (without treatment) with variations in clay (Mortmorillonite) elevations of $40 \mathrm{~cm}, 60 \mathrm{~cm}$ and $80 \mathrm{~cm}$, with pvalue $<\alpha(0.05)$ which means significantly different. The most effective treatment group is the 
treatment with variations in elevation of $80 \mathrm{~cm} / 100$ minutes with a significance value of the smallest np-value (0.000) and the highest average value of difference (0.030). The change in effectiveness that occurs in the concentration of lead $(\mathrm{Pb})$ is a decrease, thus it can be concluded that the more the variation in elevation of pillared clay (Mortmorillonite), the more significant or the more effective the decrease in the concentration of lead $(\mathrm{Pb})$ obtained.

\section{b. Concentration of Chromium $(\mathrm{Cr})$}

The test result of sea water containing Cr towards Montmorillonitewith the variation in elevation is presented in table 3 .

Table 3. Concentration of $\mathrm{Cr}$ in three times of repetition.

\begin{tabular}{|c|c|c|c|c|c|}
\hline Treatment & $\begin{array}{c}\text { Control } \\
(\mathrm{mg} / \mathrm{L})\end{array}$ & $\begin{array}{c}40 \mathrm{~cm} / 100 \\
\text { minutes } \\
(\mathrm{mg} / \mathrm{L})\end{array}$ & $\begin{array}{c}60 \mathrm{~cm} / 100 \\
\text { minutes } \\
(\mathrm{mg} / \mathrm{L})\end{array}$ & $\begin{array}{c}80 \mathrm{~cm} / 100 \\
\text { minutes } \\
(\mathrm{mg} / \mathrm{L})\end{array}$ & $\begin{array}{c}\text { Quality } \\
\text { Standards }\end{array}$ \\
\hline 1 & \multirow{7}{*}{0.0052} & 0.0044 & 0.0036 & 0.0026 & \multirow{7}{*}{$\begin{array}{c}0.005 \mathrm{mg} / \mathrm{l} \\
\text { Kepmen } \\
\text { LH } \\
\text { 51/MenLH } \\
/ 2004\end{array}$} \\
\hline 2 & & 0.0038 & 0.0035 & 0.0025 & \\
\hline 3 & & 0.0042 & 0.0031 & 0.0028 & \\
\hline Minimum & & 0.0038 & 0.0031 & 0.0025 & \\
\hline Maximum & & 0.0044 & 0.0036 & 0.0028 & \\
\hline Mean & & 0.0041 & 0.0034 & 0.0026 & \\
\hline SD & & 0.00305 & 0.00264 & 0.00152 & \\
\hline
\end{tabular}

Data Source : Analysis in 2018

Table 3 shows the concentration of $\mathrm{Cr}$ control at $0.0052 \mathrm{mg} / \mathrm{L}$, after flowing through Montmorillonite, the decrease in concentration occurs. Decrease in concentration occurs in three variations in elevation with media length of Montmorillonite of $40 \mathrm{~cm}, 60 \mathrm{~cm}$ and $80 \mathrm{~cm}$, the lowest decreases in sequence reach $0.0042 \mathrm{mg} / \mathrm{L}, 0.0031 \mathrm{mg} / \mathrm{L}$ and $0.0025 \mathrm{mg} / \mathrm{L}$.

Table 4. Percentage of Decrease of Concentration of $\mathrm{Cr}$

\begin{tabular}{c|c|c|c}
\hline \multirow{2}{*}{ Treatment } & $\begin{array}{c}\text { Control } \\
(\mathrm{mg} / \mathrm{L})\end{array}$ & $\begin{array}{c}\text { Average } \\
\text { Concentration of Cr } \\
(\mathrm{mg} / \mathrm{L})\end{array}$ & Percentage of Cr $(\%)$ \\
\hline \multirow{2}{4}{$\begin{array}{c}40 \mathrm{~cm} / 100 \\
\text { minutes }\end{array}$} & \multirow{2}{*}{0.0052} & 0.0041 & 21 \\
\cline { 1 - 1 } $\begin{array}{c}60 \mathrm{~cm} / 100 \\
\text { minutes }\end{array}$ & 0.0034 & 35 \\
\cline { 1 - 1 } $\begin{array}{c}80 \mathrm{~cm} / 100 \\
\text { minutes }\end{array}$ & & 0.0026 & 50 \\
\cline { 3 - 4 } & & &
\end{tabular}

Data Source: Analysis in 2018

Table 4 shows that for the concentration of $\mathrm{Cr}$ after flowing through Montmorillonite of 40 $\mathrm{cm}, 60 \mathrm{~cm}$ and $80 \mathrm{~cm}$ has decreased. The highest decrease is in the third treatment group, i.e. 80 $\mathrm{cm} / 100$ minutes, with a decrease of $50 \%$. 
The test analysis result of One Way Anova obtains value of Fcount (76.827) >Ftable (4.066) and p-value $(0.000)<\alpha(0.05)$, then $\mathrm{H} 0$ is rejected. This means that there is a difference in the concentration of Chromium (Cr) in sea water between pillared clay (Mortmorillonite) with variations in elevation of $40 \mathrm{~cm} / 100$ minutes, $60 \mathrm{~cm} / 100$ minutes and $80 \mathrm{~cm} / 100$ minutes.

Based on the analysis results using the LSD (Least Significant Difference) test on the treatment of variation in elevation, it can be seen the comparison between the control group (without treatment) with variations in elevation of pillared clay (Mortmorillonite) of $40 \mathrm{~cm}, 60 \mathrm{~cm}$ and $80 \mathrm{~cm}$, with p-value $<\alpha(0.05)$ which means significantly different. The most effective treatment group is treatment with variations in elevation of $80 \mathrm{~cm} / 100$ minutes with a significance value of smallest p-value $(0.00)$ and the highest average value of difference $(0.025)$. The change in effectiveness that occurs in the concentration of Chromium $(\mathrm{Cr})$ is a decrease, thus it can be concluded that the more the variation in elevation of pillared clay (Mortmorillonite), the more significant or the more effective the decrease in the concentration of Chromium (Cr) obtained.

\section{Discussion}

Kendari Bay has been polluted [14],[15], transporting heavy metals both in estuaries and in coastal areas is influenced by various factors, including liquid waste, industrial waste, urban and agricultural waste, ports, atmospheric deposition, and combined inputs from rivers around Kendari bay. This study analyzes concentrations of $\mathrm{Pb}$ and $\mathrm{Cr}$ in Kendari Bay sea water at $0.0076 \mathrm{mg} / \mathrm{L}$ and $0.0052 \mathrm{mg} / \mathrm{L}$. Although this concentration value is still in the quality standard, it must still be maintained so as not to have the effect of bio accumulation and bio magnification in the environment [16].

After the sea water which is contaminated with $\mathrm{Pb}$ and $\mathrm{Cr}$ is tested with a pillared Montmorillonite, there is a decrease in concentration. This decrease in concentration is largely determined by the length of the pillar used. The variation in elevation of the ion exchange column has an effect in decreasing $\mathrm{Pb}$ and $\mathrm{Cr}$ metals. The higher the ion exchange column used, the higher the efficiency. The best ion exchange column elevation occurs at $80 \mathrm{~cm}$ height with a decrease of $41 \%$ for $\mathrm{Pb}$ and $50 \%$ for $\mathrm{Cr}$.

The ability of clay to exchange ion in clay is caused by clay containing alumino-silicate hydrate which binds various exchange cations or anions such as $\mathrm{Ca} 2+, \mathrm{Mg} 2+, \mathrm{H}+, \mathrm{K}+, \mathrm{Na}+$, $\mathrm{NH} 4+$, SO42-, Cl-, PO43-or NO3-in the surface [17]. These ions can easily be exchanged with other ions from the outside without affecting the alumino-silicate structure of the clay [18],[19].

According to Kloprogge et al., (2002) Montmorilonite has the ability to absorb water molecules, and this process will change the distance between layers so that clay mineral of montmorilonite has an expanding structure. Clay in which its bond has been detached with water when passed by sea water, clay containing alumino-silicate hydrate will bind $\mathrm{H} 2 \mathrm{O}$ in the sea water again, so it causes the concentration of salt after flowing through the pillared clay.

Clay has pores that can be passed by water, when sea water containing $\mathrm{Cl}$-ion ( $\mathrm{Cl}$ - of Sea Water) is passed through activated clay (OH-Clay), then $\mathrm{Cl}$-ion in the sea water will replace $\mathrm{OH}-$ ion from clay so that $\mathrm{Cl}$-ion will bond to clay (Cl- Clay) and $\mathrm{OH}$-ion will bond to sea water $(\mathrm{OH}-$ of Sea Water). This occurs because $\mathrm{OH}$-ion binds weaker than clay of Cl-ion. The ability of clay to be able to exchange and bind to anions, as well as cations, depends on the hydratation and valence 
of existing ions [20]. Based on this, decrease in heavy metals and salinity by pillared Montmorillonite activity, sea water can be a source of clean water for people with limited access.

Through this study, it can also be known that the longer the length of pillared Montmorillonite, the better it is in reducing the concentration of heavy metals in sea water to be used as one of the water sources.

\section{Conclusion}

Conclusions of this study are as follows :

1. There are differences in concentrations of $\mathrm{Pb}$ and $\mathrm{Cr}$ between pillared Mortmorilonite with variations in elevation of $40 \mathrm{~cm} / 100$ minutes, $60 \mathrm{~cm} / 100$ minutes and $80 \mathrm{~cm} / 100$ minutes in sea water in the Kendari Bay area.

2. The most effective variation in elevation of pillared Montmorillonite of $80 \mathrm{~cm} / 100$ minutes in reducing concentration of $\mathrm{Pb}$ in sea water, with an average of 0.0045 , percentage of decrease is $41 \%$, LSD test result obtains the smallest value of 0.00 and the highest average difference (0.03).

3. The most effective variation in elevation of pillared Montmorillonite of $80 \mathrm{~cm} / 100$ minutes in reducing concentration $\mathrm{Cr}$ in seawater, with an average of 0.0026 , percentage of decrease is $50 \%$, LSD test result obtains the smallest value of 0.00 and the highest difference $(0.025)$.

\section{Reference}

[1] D. Zhou, L. Zhu, Y. Fu, M. Zhu, and L. Xue, "Development of lower cost seawater desalination processes using nanofiltration technologies-A review," Desalination, vol. 376, pp. 109-116, 2015.

[2] A. Pruss-Ustun and W. H. Organization, "Safer water, better health: costs, benefits and sustainability of interventions to protect and promote health", 2008.

[3] E. A. Jayadipraja, A. Daud, and A. H. Assegaf, "Air Pollution and Lung Capacity of People Living around the Cement Industry," Public Health of Indonesia, vol. 2, pp. 76-83, 2016.

[4] G. Nabi, M. Ali, S. Khan, and S. Kumar, "The crisis of water shortage and pollution in Pakistan: risk to public health, biodiversity, and ecosystem," Environmental Science and Pollution Research, pp. 1-3, 2019.

[5] J. N. Halder and M. N. Islam, "Water pollution and its impact on the human health," Journal of environment and human, vol. 2, pp. 36-46, 2015.

[6] M. S. Islam, M. K. Ahmed, M. Raknuzzaman, M. Habibullah-Al-Mamun, and M. K. Islam, "Heavy metal pollution in surface water and sediment: a preliminary assessment of an urban river in a developing country," Ecological indicators, vol. 48, pp. 282-291, 2015.

[7] R. Nazir, M. Khan, M. Masab, H. U. Rehman, N. U. Rauf, S. Shahab, et al., "Accumulation of heavy metals $(\mathrm{Ni}, \mathrm{Cu}, \mathrm{Cd}, \mathrm{Cr}, \mathrm{Pb}, \mathrm{Zn}, \mathrm{Fe})$ in the soil, water and plants and analysis of physico-chemical parameters of soil and water collected from Tanda Dam Kohat," Journal of Pharmaceutical Sciences and Research, vol. 7, p. 89, 2015.

[8] S. M. Indirawati, S. Pandia, H. Mawengkang, and W. Hasan, "Inverse Distance Weighted Method and Environmental Health Risks of Plumbum Pollution in Drinking Water in 
Belawan Coastal Area," Advanced Science Letters, vol. 23, pp. 3339-3343, 2017.

[9] E. Riani, M. R. Cordova, and Z. Arifin, "Heavy metal pollution and its relation to the malformation of green mussels cultured in Muara Kamal waters, Jakarta Bay, Indonesia," Marine pollution bulletin, vol. 133, pp. 664-670, 2018.

[10] M. K. Uddin, "A review on the adsorption of heavy metals by clay minerals, with special focus on the past decade," Chemical Engineering Journal, vol. 308, pp. 438-462, 2017.

[11] A. Taha, M. A. Shreadah, A. Ahmed, and H. F. Heiba, "Multi-component adsorption of Pb (II), Cd (II), and Ni (II) onto Egyptian Na-activated bentonite; equilibrium, kinetics, thermodynamics, and application for seawater desalination," Journal of environmental chemical engineering, vol. 4, pp. 1166-1180, 2016.

[12] T. Germanova, V. Nefedov, and I. Valieva, "The Survey of Sorption Ion-Exchange Properties of Paleozoic Natural Minerals in the Static Conditions," in IOP Conference Series: Earth and Environmental Science, p. 012011, 2017.

[13] X. Zheng, J. Dou, J. Yuan, W. Qin, X. Hong, and A. Ding, "Removal of Cs+ from water and soil by ammonium-pillared montmorillonite/Fe3O4 composite," Journal of Environmental Sciences, vol. 56, pp. 12-24, 2017.

[14] A. Armid, R. Shinjo, and R. Ruslan, "Distributions and pollution assessment of heavy metals $\mathrm{Pb}, \mathrm{Cd}$ and $\mathrm{Cr}$ in the water system of Kendari Bay, Indonesia," in IOP Conference Series: Materials Science and Engineering, p. 012002, 2017.

[15] K. Sari, "Analisis Sedimen Di Teluk Kendari Menggunakan GWR Berdasarkan Komposisi Logam Berat $\mathrm{Pb}, \mathrm{Cd}$ dan $\mathrm{Cr}$," ed: Skripsi Jurusan Matematika. Kendari: Universitas Halu Oleo, 2016.

[16] E. Barón, J. Giménez, P. Verborgh, P. Gauffier, R. De Stephanis, E. Eljarrat, et al., "Bioaccumulation and biomagnification of classical flame retardants, related halogenated natural compounds and alternative flame retardants in three delphinids from Southern European waters," Environmental pollution, vol. 203, pp. 107-115, 2015.

[17] K. G. Bhattacharyya, S. S. Gupta, and G. K. Sarma, "Kinetics, equilibrium isotherms and thermodynamics of adsorption of Congo red onto natural and acid-treated kaolinite and montmorillonite," Desalination and water treatment, vol. 53, pp. 530-542, 2015.

[18] K. G. Akpomie, F. A. Dawodu, and K. O. Adebowale, "Mechanism on the sorption of heavy metals from binary-solution by a low cost montmorillonite and its desorption potential," Alexandria Engineering Journal, vol. 54, pp. 757-767, 2015.

[19] I. Ghorbel-Abid and M. Trabelsi-Ayadi, "Competitive adsorption of heavy metals on local landfill clay," Arabian Journal of Chemistry, vol. 8, pp. 25-31, 2015.

[20] U. Khairunnisa, S. Elystia, and Z. Zultiniar, "Efisiensi Penurunan Kadar Natrium (Na+) Dan Klorida (Cl-) Pada Air Laut Menggunakan Tanah Lempung Dengan Metode Penukar Ion," Jurnal Online Mahasiswa (JOM) Bidang Teknik dan Sains, vol. 2, pp. 1-7, 2015. 